\title{
Corporate Governance and Survival of Telecommunication Firms in Port Harcourt, Rivers State.
}

\author{
Chukwudifu, Angela Awele \\ Business School, University of Port Harcourt, Rivers State, Nigeria \\ Olori, Williams Onoriode \\ Department of Management, University of Port Harcourt, Rivers State, Nigeria
}

\begin{abstract}
This study investigated the correlation between corporate governance and firm survival of telecommunication firms in Port Harcourt, Rivers State, Nigeria. The cross -sectional survey research design was applied. Data for the research was collected through questionnaire administered to 51 management staff of four telecommunications firms of which 44 were usable. The data was analysed by the use of Spearman Rank Order Correlation Co-efficient and hypothesis were tested by method of $p$ value. The outcome of the hypotheses test indicates that there is a significant relationship between the dimensions of corporate governance (board independence and transparency) and the measures of the firms' survival (adaptability and innovation). Based on the findings, it was recommended that the management and other decision makers in telecommunication firms should formulate policies that promote the adoption of independence of board members, so that the organization can quickly adapt to changes that arises within the industry they operate in and should promote transparent practices as this will instil confidence and trust amongst stakeholders and ensure business survival.
\end{abstract}

Keywords: Adaptability; Board Independence; Corporate Governance; Innovation; Organisational Survival; Transparency.

DOI: $10.7176 / \mathrm{EJBM} / 12-10-08$

Publication date: April $30^{\text {th }} 2020$

\section{Introduction}

Survival in the business world, can be seen as the company's capacity to withstand adverse business conditions such as recession, depression, and remain profitable to meet its financial and other organisational objectives. To accomplish these goals, businesses mobilize financial, human and other resources, generate value for their continual existence and strive to make a profit geared towards continuity of their operations. This is because unprofitable business operations will in no time result in business failure. In today's information age, corporate governance is paramount in terms of firms' competitiveness, growth, survival and sustainability. Corporate governance according to Organisation for Economic Co-operation and Development (OECD) as cited in Lazonick, and O'sullivan (2000) is a vital element in improving economic efficiency involving the array of existing relationships between a company's management, its board, shareholders and other stakeholders that builds the foundation upon which the goals of the company is rooted, and the various ways (strategy) of attaining these objectives and keeping track of performance are determined. Furthermore, a blueprint should be generated by good corporate governance and a good stimulus package for the board and executives in pursuance of objectives that are of importance to the firm and its shareholders (OECD as cited in Lazonick, \& O'sullivan, 2000). Since corporate governance is the system by which organisations are managed and controlled and board of directors are held to account for presiding over the affairs of the company and development of firm's strategy, Pass (2004) stated that a firm's survival is affected by corporate governance attributes. The Asian financial crisis of 1997 turned the spotlight on its importance, noting that good corporate governance is significant for the longterm survival of companies. This was corroborated by Porter (1991) who stated that the reason why firms succeed or fail is perhaps the central question of strategy.

However, despite the well-known generic strategies espoused in literature, international telecom firms at the moment are taking into consideration socially responsible behaviours as a workable strategy for survival with the aim of gaining and sustaining customers patronage (Berkhout, 2005; Porter \& Kramer, 2006; Nsikan, Umoh, \& Bariate, 2015). It is imperative that without a corporate strategy to attain certain corporate objectives, the survival of the telecom industry will be threatened in Nigeria; this is because it is perceived to be a corporate management approach with the aim of satisfying the critical objectives of all stakeholders while complying with 
the legal, ethical and environmental needs of the society. It is notable that most firms experience a stall in growth after getting to a particular phase, as they make efforts to maintain the pre-existing state of affairs and are reluctant to fully implement corporate governance code. However, in Nigeria, it is important to point out that her economic growth of $6.9 \%$ in 2009 was as a result of the expansion in Nigeria's telecom industry. The oil and gas sector witnessed a decrease of $1.2 \%$ while the telecommunications industry enjoyed an unprecedented growth of $34.2 \%$ in 2009. (Bloomberg Business Week as cited in Ogbo, Okechukwu, \& Ukpere, 2012). A comprehensive adoption of corporate governance in running businesses is likely to improve their competitiveness and performance because telecommunication industry facilitates economic activities in the current century through information and communications technology like, e-banking, e-commerce, e-payment, e-education, e-health, eagriculture etc. and also because of how critical the industry is to Nigeria's economy. This in essence implies that the Nigerian telecommunication should be prepared to review their formalization, centralization and specialization processes on a continuous basis as their survival chances may be seriously threatened, which may lead to revenue loss, closures and increased unemployment.

It is further observed that in Nigeria poor corporate governance has led to failure of telecommunication firms, such as: Mtel, Nitel and Econet. In view of the aforementioned, Goktan, Kieschnick, and Moussawi (2006) observed that the chances of a firms survival is affected by corporate governance.

In this study, two operational measures each of corporate governance (board independence and transparency) organizational survival (adaptability and innovation) were used and these gave rise to four corresponding hypotheses stated in their null forms as follow:

Hypotheses

$\mathrm{H} 0_{1}$. There is no significant relationship between board independence and adaptability

$\mathrm{HO}_{2}$. There is no significant relationship between board independence and innovation

$\mathrm{HO}_{3}$. There is no significant relationship between transparency and adaptability

$\mathrm{H}_{4}$. There is no significant relationship between transparency and innovation

\section{Literature Review}

\section{Theoretical Framework}

This research was based on the following theories: Agency Theory; Network Theory; Population Ecology theory; and Resource Dependency Theory. Agency Theory state that corporate goal will be best achieved if a group of person manage the corporation on behalf of the owners and other stakeholders (Fligstein, 2001). The proponents assert that in modern corporation, where share ownership is widely held, managerial actions are inconsistent with those needed to maximize shareholders returns. This theory is considered because the cardinal objective of strategic management is to point out how organisations can be administered to gain comparative advantage. This suggests that organisations can maximize the economic effects of the disconnection of ownership and control of business if the appropriate administrative apparatus are set up. Social Network Theory propounded by Weicked in 1969 deals with repeated interactions among social networks. Pfeffer (1982) posits that social interaction is amongst the pillars on which organisational survival is rested. It is however, established on the basis of social interaction and it vividly claims to be connected with relationships between interacting entities. Population Ecology which extensively addressees the issue of organisational success and survival, it states that environment determines the likelihood of success or failure of organisations. Resource Dependency Theory believes that organisational behavior becomes externally influenced because the focal organisation must attend to the demands of those environment that provide resources necessary and crucial for its continued survival.

\section{The Concept of Corporate Governance}

Corporate governance is a broad term that seeks to define the procedures, pattern and the procedures of a firm in ways they are been handled and maintained, while enhancing shareholder value in the long term by practice of accountability of its administrators, it promotes or strengthens the achievement of the firm, eliminate clash of ownership and management and clearly outline the interest of shareholders and managers (Khan, 2011). Oman (2001) stated that corporate governance refers to "private and public institutions that include laws, regulations and the business practices which govern the relationship between the corporate managers and the stakeholders". 
Good corporate governance however represents both enterprise (performance) and accountability (conformance). Denis and McConnell (2003) opined that the essence of corporate governance in corporate groups is to reduce conflicts of interest and monitoring of controlling interest of the firm, the absence of which the firms' value may decrease. Good corporate governance aids the prioritization of organizational objectives and achieve good corporate performances, enhance ethical decisions making within organization where shareholders concerns and stakeholders interest are addressed properly (Sanda, Mikailu, \& Garba, 2005; Wieland, 2009).

\section{Board Independence}

The concept of board independence is a primal factor, for it ensures board proficiency through supervision and specific duties of the directors. However, the determining factor for board independence is getting sufficient numbers of independent directors aboard (Berghe \& Baelden, 2005). Furthermore, the director's capability, readiness and board environment might foster the independent attitude of each director. One of the essential roles of independent board is to supervise the company's productivity and operations. Effective monitoring tools in the company could reduce problems that plague the agency. Thus, the company should elect autonomous and self-determining directors who could make use of proper oversight function in monitoring governance, internal control and risk management. However, Hermalin and Weisbach (1991) found no relationship between firm performance and the proportion of outside directors.

\section{Transparency}

In different circumstances, transparency is an integral part of effective organizing (Fleischmann \& Wallace, 2005). It is viewed as the level of perceived comprehensibility, wholeness, and exactness in institutional communications, (Bloomfield \& O'Hara, 1999). Transparency is profitable to governance in any organisation in that it reduces the cost of trading the firm's securities and the firm's financing and also improves the board's monitoring of the Chief Executive Officer (CEO) by providing them with an information about his or her performance.

\section{Organizational Survival}

Organisations strive to pull through in the corporate world and tries to satisfy the increasing dictates on firms. Researchers and philosophers subscribe to the perspective that organizational survival is an implicit organizational goal requiring the investment of energy and resources (Jones \& Bartlet, as cited in Adewale, Abolaji, \& Kolade, 2011). Gross also as cited in Adewale et al., (2011) stressed that the goal of organizational survival strengthens all other objectives and that the notion of survival is an unwritten law of every organization, which means that every organization should see survival as a total requirement. This study focuses on adaptability and innovation as measures of survival.

\section{Adaptability}

Adaptability signifies firms' capability to respond speedily to opportunities and risks and convert same into its advantages (Macmillan \& Tampoe, 2000). It is the capacity to acknowledge the demands of customers and clients, the aptitude to make optimum choices, an intentional response to change while rooted on information surrounding its environment; while having in mind that people are the ones who must adapt not organizations. As a result, employees should be at liberty to build new capabilities and adjust their behaviors when necessary. Furthermore, adapting to changes in business environments has to do with a continual exercise that involves resources in an organization. When organizations are adaptive, coordination between specialized workers can be achieved through effective communication. On the whole, organizational success depends on amongst others, how well each of its policies/procedures adapt to its own peculiar demands and how well all tasks are coordinated with one another (Dessein \& Santos, 2006; Bolton \& Dewatripont, 1994; Garicano, 2000).

\section{Innovation}

Organisations innovativeness has begun to stir curiosity in this present day noting that firms progressively needs to depend on varying degrees, and several external sources of information. This directly implies that being innovative is advantageous in numerous ways: in disseminating information, lowering transaction costs, building up the possibility for the division of labour between enterprises and fostering collective action. While having in mind that it is systemic and therefore behoves on organisations to maintain a system that upgrades knowledge from time to time. It is usually difficult for one firm to possess all the knowledge and capabilities required to innovate, this implies that there will always be certain inputs into the innovation process, especially knowledge 
and capabilities, which the firm does not possess in-house and had to be sought for outside the confines of the organization. Therefore as integral to the innovation process, firms need to engage in a search for complementary knowledge and capabilities beyond their boundaries (Chesbrough, 2003). The power to conceive and initiate is always one factor that makes for the success of an organization. Organizations that possess the necessary resources to innovate and an organizational climate that encourage innovative ideas, are exactly those that will innovate rapidly and successfully (Lawson, \& Samson, 2001). According to Damanpour (1996), the capacity to innovate is indicative of the ability to continuously create new knowledge and ideas, and that the innovation process is very complex and multidimensional because many factors interact to make possible the emergence of this process.

\section{Board Independence and Firm Survival}

Board members may develop their human capital by learning from past failures and utilize this knowledge to reduce the chance of organisations failing in subsequent ventures. On the other hand, past failures may create barriers to learning and reduced reputational capital and ability to galvanize support from external parties if the organization goes into distress (Wiesenfeld, Wurthmann, \& Hambrick, 2008)

Older board members may be more experienced and better able to use that experience to adapt to market changes that may potentially threaten survival. Older directors can bring greater stability to the board and can preserve founding values (Anderson, Reeb, Upadhyay, \& Zhao, 2011)

Board independence aid Directors in organisations serving on multiple boards improve their skills, knowledge, and comparative capital with trading partners, providing expertise to help avoid distress and, an ability to obtain extended credit terms in times of trading difficulty (Arregle, Hitt, Sirmon, \& Very, 2007). The outcome of the research of Armstrong, Core, \& Guay (2013) showed that, an 18\% increase of the self-determining directors' number resulted in a decrease of $6 \%$ in the companies' informational irregularity; as such they are given to the outlook that though independent board have access to internal reports and information, but are more ready to underpin their decisions on corporate information disclosed by other sources. Berglof and Pajuste (2005); Girbina, Albu, and Albu (2012); Johari, Saleh, Jaafar and Hassan (2008) stated that a large number of independent directors in a company may not necessarily increase the shareholders wealth.

\section{Transparency and Organisation's Survival:}

Research work by Mankins and Steele (2005) indicated that companies normally fail to get up to forty percent of expected earnings due to uncommitted employees that are not adequately trained to contribute meaningfully. While a good knowledge and thorough harmonization of each employee's objectives with a company's overall plans is crucial towards implementing it, the key to achieve the optimal performance of a company is dependent on motivated employees (Sirota, Mischkind, \& Meltzer, 2005). It is sometimes difficult to ascertain what factor will stimulate a worker's commitment in the achievement of organizational goal. Preferences, attitudes towards work, and motivation change over time in the cycle of each individuals working life hence the increasing demand for talent and a shortage of skilled employees. Such shortage has increased companies' awareness and acknowledgement of the fundamental role of human capital in its strategic planning and utilization of human capital. It is costly to retain poorly performing employees but organisations also incur a significant cost when talented employees voluntarily leave. The effect of losing skilled staff manifest through fall in output as it takes time and resources to get replacement and groom another who can work at the same level of productivity. Therefore, companies that fail to understand what motivates employees' overtime are unlikely to get the most from them (Pfeffer \& Sutton, 2006). This proves that openness in communication will not only encourage employees but will stimulate them to do more thereby improving on productivity, and enhance the possibility of achieving set goals.

\section{Methodology}

This study employed the use of the cross-sectional survey research design in studying population of 51 management staff of telecommunication firms operating in Port Harcourt distributed as follows: MTN Nigeria, 17; Glo Nigeria, 15; 9Mobile, 11; and Airtel, 8. Given the small size of numbers of executives in the firms, a census study was adopted. Corporate governance (the predictor) was operationally measured using two variable namely: board independence and transparency with each dimension measured on a four - item instrument adopted from Ogbechie and Koufopoulos (2010) Corporate Governance Questionnaire, while the criterion variable; firms' survival was operationally measured using adaptability and innovation; on a four item instrument adopted from Ahmed, and Zairi (2012) Organisations Survival Questionnaire. The primary data were 
generated using a 5-point Likert type questionnaire. The Cronbach Alpha was adopted to test the reliability of the constructs and results are as follow: Transparency, 0.851; Board Independence, 0.791; Adaptability, 0.829; and Innovation, 0.888. These result showed high reliability of the instrument. The hypotheses were tested at 0.05 level of significance using Spearman Rank Order Correlation aided by statistical package for social sciences (SPSS) version 21.

\section{Results}

\section{Hypothesis (H01):There is no significant relationship between board independence and adaptability}

Table 1: Correlations for Board Independence and Adaptability

\begin{tabular}{|c|c|c|c|c|}
\hline \multirow{2}{*}{\multicolumn{2}{|c|}{ Spearman's rho Independence }} & & Independence & Adaptability \\
\hline \multirow[t]{6}{*}{ Spearman's rho } & & Correlation Coefficient & 1.000 & $.690^{* *}$ \\
\hline & & Sig. (2-tailed) & . & .000 \\
\hline & & $\mathrm{N}$ & 44 & 44 \\
\hline & Adaptability & Correlation Coefficient & $.690^{* *}$ & 1.000 \\
\hline & & Sig. (2-tailed) & .000 & . \\
\hline & & $\mathrm{N}$ & 44 & 44 \\
\hline
\end{tabular}

The result shows a significant correlation exists between board independence and adaptability $($ rho $=0.690, \mathrm{p}<0.05)$.

Hypothesis $\left(\mathrm{HO}_{2}\right)$ : There is no significant relationship between board independence and innovation Table 2: Correlations for Board Independence and Innovation

\begin{tabular}{|c|c|c|c|c|}
\hline \multirow{2}{*}{\multicolumn{2}{|c|}{ Spearman's rho Independence }} & & Independence & Innovation \\
\hline \multirow[t]{6}{*}{ Spearman's rho } & & Correlation Coefficient & 1.000 & $.603^{* *}$ \\
\hline & & Sig. (2-tailed) & 年 & .000 \\
\hline & & $\mathrm{N}$ & 44 & 44 \\
\hline & Innovation & Correlation Coefficient & $.603^{* *}$ & 1.000 \\
\hline & & Sig. (2-tailed) & .000 & . \\
\hline & & $\mathrm{N}$ & 44 & 44 \\
\hline
\end{tabular}

The result in table 2 shows that there is a significant relationship between board independence and innovation $($ rho $=0.603, \mathrm{p}<0.05)$.

$\mathrm{HO}_{3}$ : there is no significant relationship between transparency and adaptability. Table 3: Correlations for Transparency and Adaptability

\begin{tabular}{|c|c|c|c|c|}
\hline & & & Transparency & Adaptability \\
\hline \multirow[t]{6}{*}{ Spearman's rho } & Transparency & Correlation Coefficient & 1.000 & $.502^{* *}$ \\
\hline & & Sig. (2-tailed) & . & .000 \\
\hline & & $\mathrm{N}$ & 44 & 44 \\
\hline & Adaptability & Correlation Coefficient & $.502^{* *}$ & 1.000 \\
\hline & & Sig. (2-tailed) & .000 & 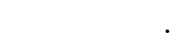 \\
\hline & & $\mathrm{N}$ & 44 & 44 \\
\hline
\end{tabular}

The result in table 3 shows a significant correlation coefficient between transparency and adaptability (rho = $0.502, \mathrm{p}<0.05)$. 
$\mathrm{H0}_{4}$ : there is no significant relationship between transparency and innovation. Table 4: Correlations for Transparency and Innovation

\begin{tabular}{lllrr}
\hline & & Transparency & Innovation \\
\hline Spearman's rho & Transparency & Correlation Coefficient & 1.000 & $.693^{* *}$ \\
& & Sig. (2-tailed) &. & .000 \\
& N & Correlation Coefficient & $.693^{* *}$ & 44 \\
& & Sig. (2-tailed) & .000 & 1.000 \\
& & N & 44 & 44 \\
\hline
\end{tabular}

**. Correlation is significant at the 0.05 level (2-tailed).

Table 4 shows the rho result between transparency and innovation thus: (rho $=0.693, p<0.05$ ). This implies that there is significant relationship between transparency and innovation.

\section{Discussion}

The results of the hypotheses test on the relationship between corporate governance dimensions and measure of firm's survival revealed that there is a positive and significant correlation between the variables. This shows that the more independent the board and transparent the organization is, the higher the chance of organization's ability to innovate and adjust to transformations in the work environment which leads to greater chances of survival. This finding resonate with Arregle, et al., (2007) which states that board independence aid Directors in organisations to improve their skills and knowledge to avoid distress and an ability to obtain extended credit terms in times of financial difficulty. This finding is also tandem with the views expressed by Sirota et al., (2005) who stated that a good knowledge and thorough harmonization of each employee's objectives with a company's overall plans is crucial towards implementation of plans. It can therefore be stated that corporate governance in terms of board independence and transparency promotes and instils survival in terms of adaptability and innovativeness.

\section{Conclusion}

The research revealed that Board independence and transparency significantly and positively correlate with organizational survival as they influence adaptability and innovativeness of telecommunication industry in Port Harcourt. As a result, it is recommended that the telecommunication industry decision makers and shareholders should formulate policies that promote the acceptance of the independence of board members in order for the organization to adapt swiftly to changes arising within the industry in which they operate. This is as a result of the stiff competition in the telecommunication sector as survival has become crucial and requires deliberate strategies to adjust to the ever-changing environment in they operate. In addition, telecommunication operators should promote transparent practices as this will promote cooperation from different stakeholders that will enable firms to survive in the long-run.

\section{References}

Abdul-Rahman, R., \& Mohamed, A. F. H. (2006). Board, audit committee, culture and earnings management: Malaysian evidence. Managerial Auditing Journal, 21(7), 783-804.

Adewale, O. O., Abolaji, A. J., \& Kolade, O. J. (2011). Succession planning and organizational survival: Empirical study on Nigerian private tertiary institutions. Serbian Journal of Management, 6(2), 231-246.

Ahmed, P. K., \& Zairi, M. (2012). Innovation: A performance measurement perspective. In From Knowledge Management to Strategic Competence: Assessing Technological, Market and Organisational Innovation (pp. 307-341).

Anderson, R. C., Reeb, D. M., Upadhyay, A., \& Zhao, W. (2011). The economics of director heterogeneity. Financial Management, 40(1), 5-38.

Armstrong, C., Core, J., \& Guay, W. (2013). Do independent directors cause improvements in firm transparency? Working paper. 
Arregle, J. L., Hitt, M. A., Sirmon, D. G., \& Very, P. (2007). The development of organizational social capital: Attributes of family firms. Journal of management studies, 44(1), 73-95.

Berghe, V. D \& Baelden, T. (2005). The complex relation between director independence and board effectiveness. Corporate Governance: The International Journal of Business in Society, 5(5), 61-83

Berglöf, E., \& Pajuste, A. (2005). What do firms disclose and why? Enforcing corporate governance and transparency in Central and Eastern Europe. Oxford Review of Economic Policy, 21(2), 178-197.

Berkhout, T. (2005). Corporate social responsibility can be the strategic engine for long-term corporate profits and responsible social development. Alternatives Journal, 31, 124-138

Bloomfield, R., \& O'Hara, M. (1999). Market Transparency: Who Wins and Who Loses? The Review of Financial Studies, 12(1), 5-35.

Bolton, P., \& Dewatripont, M. (1994). The firm as a communication network. The Quarterly Journal of Economics, 109(4), 809-839.

Chesbrough, H.W. (2003). Open innovation: The new imperative for creating and profiting from technology. Oxford University Press, Oxford.

Damanpour, F. (1996). Organizational complexity and innovation: Developing and testing multiple contingency models. Management science, 42(5), 693-716.

Denis, D. K., \& McConnell, J. J. (2003). International corporate governance. Journal of financial and quantitative analysis, 38(1), 1-36.

Dessein, W., \& Santos, T. (2006). Adaptive organizations. Journal of Political Economy, 114(5), 956-995.

Fleischmann, K. R., \& Wallace, W. A. (2005). A covenant with transparency: Opening the black box of models. Communications of the ACM, 48, 93-97.

Fligstein, N. (2001). Social skill and the theory of fields. Sociological theory, 19(2), 105-125.

Garicano, L. (2000). Hierarchies and the organization of knowledge in production. Journal of Political Economy, 108(5), 874-904.

Girbina, M.M., Albu, N \& Albu, C.N. (2012). Corporate Governance Disclosures in Romania: Board directors and corporate social responsibility. Palgrave: Macmillan.

Goktan, M. S., Kieschnick, R., \& Moussawi, R. (2006). Corporate governance and corporate survival. Texas: University of Texas.

Hermalin, B., \& Weisbach, M. (1991). The effects of board composition and direct incentives on firm performance. Financial Management, 20, 101-112.

Jesover, F. \& Kirkpatrick, G. (2005). The revised OECD principles of corporate governance and their relevance to non-OECD countries. Corporate Governance: An International Review, 13, 127-36.

Johari, N. H, Saleh, N. M., Jaafar, R \& Hassan, M. S. (2008). The Influence of board independence, competency and ownership on earnings management in Malaysia. International Journal of Economics and Management, 2(2), 281-306.

Kaplan, R. \& Norton, D. (2006). Alignment. Boston MA: Harvard Business School Press.

Khan, H. (2011). A literature review of corporate governance. In International Conference on E-business, Management and Economics, 25, 1-5. 
Lawson, B., \& Samson, D. (2001). Developing innovation capability in organisations: A dynamic capabilities approach. International journal of innovation management, 5(03), 377-400.

Lazonick, W., \& O'sullivan, M. (2000). Maximizing shareholder value: A new ideology for corporate governance. Economy and society, 29(1), 13-35.

Macmillan, H., \& Tampoe, M. (2000). Strategic management: Process, content, and implementation. Oxford: Oxford University Press.

Mankins, M., \& Steele, R. (2005). Turning great strategy into great performance. Boston MA: Harvard Business Review

Nsikan, J. E., Umoh, V. A., \& Bariate, M. (2015). Corporate social responsibility and mobile telecommunication competitiveness in Nigeria: The case of MTN Nigeria. American Journal of Industrial and Business Management, 5(08), 527-537

Ogbechie, C., \& Koufopoulos, D. N. (2010). Board effectiveness in the Nigerian Banking industry. Retrieved on 13/12/2019 from https://ssrn.com/abstract=1570247

Ogbo, A. I., Okechukwu, I., \& Ukpere, W. I. (2012). Managing innovations in telecommunications industry in Nigeria. African Journal of Business Management, 6(25), 7469-7477.

Oman, C. P. (2001). Corporate governance and national development. OECD Development Centre Working Papers 180, OECD Publishing.

Pass, C. (2004). Corporate governance and the role of non-executive directors in large UK companies: An empirical study. Corporate Governance, 4(2), 52-63.

Pfeffer, J. \& Sutton, R. (2006). Hard facts, dangerous half-truths \& total nonsense: Profiting from evidence based management. Boston, MA: Harvard Business Review.

Pfeffer, J. (1982). Organizations and organization theory. Boston: Pitman.

Porter, M. E., \& Kramer, M. R. (2006). The link between competitive advantage and corporate social responsibility. Harvard business review, 84(12), 78-92.

Porter, M. E. (1991). Towards a dynamic theory of strategy. Strategic Management Journal, 12(1), 95-117.

Sanda, A., Mikailu, A., \& Garba, T. (2005). Corporate governance mechanisms and firm financial performance in Nigeria. African Economic Research Consortium, Research Paper, 149, Nairobi.

Sirota, D., Mischkind, L., \& Meltzer, M. (2005). The enthusiastic employee: How companies profit by giving workers what they want. Philadelphia, PA: Wharton School Publishing.

Van den Berghe, L. A., \& Baelden, T. (2005). The monitoring role of the board: one approach does not fit all. Corporate Governance: An International Review, 13(5), 680-690.

Wieland, J. (2009). Corporate governance, values, management, and standards: A European perspective. In European Corporate Governance (pp. 81-92). Routledge.

Wiesenfeld, B. M., Wurthmann, K. A., \& Hambrick, D. C. (2008). The stigmatization and devaluation of elites associated with corporate failures: A process model. Academy of management review, 33(1), 231-251. 